\title{
Multiple fractures in infancy: scurvy or nonaccidental injury?
}

This article was published in the following Dove Press journal:

Orthopedic Research and Reviews

8 September 2010

Number of times this article has been viewed

\section{Colin R Paterson}

Formerly of Department of Medicine, University of Dundee, Dundee, Scotland, UK
Correspondence: Colin R Paterson Temple Oxgates, Longforgan, Dundee DD2 5HS, Scotland, UK

$\mathrm{Tel}+44$ I382360240

Email c.s.paterson@btinternet.com
Abstract: The child with unexplained fractures has a differential diagnosis that includes nonaccidental injury but also a number of bone disorders including osteogenesis imperfecta and rickets. This paper reports a 14-month-old girl who was found to have seven fractures, several hematomas and widespread sub-periosteal reactions. She was found to have biochemical evidence of vitamin $\mathrm{C}$ deficiency. While nonaccidental injury could not be excluded, it seemed likely that the major cause of the fractures was scurvy. It is important to consider the whole differential diagnosis in a child with unexplained fractures.

Keywords: scurvy, vitamin $\mathrm{C}$ deficiency, nonaccidental injury, fractures, ascorbic acid

\section{Introduction}

The child presenting with fractures that the parents cannot explain provides the pediatrician or orthopedic surgeon with an urgent problem of differential diagnosis. One possibility is nonaccidental injury, it being assumed that the parents are denying assaults that they or others have inflicted. However a wide variety of bone disorders also cause unexplained fractures. The best known of these is osteogenesis imperfecta. ${ }^{1}$ Others include vitamin D deficiency rickets, ${ }^{2,3}$ bone disease of prematurity, ${ }^{4}$ copper deficiency, ${ }^{5}$ Menkes' kinky hair disease $^{6,7}$ and, more controversially, temporary brittle bone disease. ${ }^{8,9}$

Copper deficiency and Menkes' disease are thought to cause fractures by impairing the formation of collagen; copper is essential for this process. Vitamin $\mathrm{C}$ is also essential for collagen formation and fractures, including metaphyseal fractures, have been reported in scurvy. ${ }^{10,11}$ Fractures are well recognized in laboratory animals with scurvy including macaque monkeys. ${ }^{12}$ Multiple spontaneous fractures also occur in other animals with mutations affecting the synthesis of ascorbic acid, including rats, mice, and pigs. ${ }^{13-15}$

This paper reports one child with multiple fractures initially thought to be caused by nonaccidental injury in whom there was biochemical evidence of vitamin $\mathrm{C}$ deficiency. There is only one similar report in the literature: a boy aged 32 months with a fracture of the upper left humerus. ${ }^{16}$ There is also one report of an 11-month-old girl with a transverse fracture of the right femur who was thought to have had both rickets and scurvy. ${ }^{17}$

\section{Case report}

A girl aged 14 months was admitted to hospital because her mother had noticed a large bruise over the left clavicle. She had for some days appeared to be in pain when handled but had been seen and examined by a general practitioner who thought that she had 
a viral infection. There was no clear history of trauma but it was thought that there might have been a fall from a pushchair three weeks earlier when taken out by a neighbour's teenage daughter. No bruises had been seen by relatives or by the general practitioner prior to the day of admission.

There was no family history to suggest osteogenesis imperfecta and no relevant physical signs. There was no family history of any bleeding disorder.

On examination there was a large hematoma overlying the left clavicle, a greatly swollen and discolored right thigh and a small bruise over the left wrist. Radiography revealed a recent oblique fracture of the right upper femur, a recent fracture of the left clavicle and old fractures of the right clavicle, left tibia (Figure 1), the left ulna (Figure 2), the right femur, and the lower pole of the right scapula. There was an extensive hematoma of the right thigh and widespread calcified subperiosteal reactions.

Further investigation demonstrated a hypochromic microcytic anemia. An ascorbic acid saturation test was

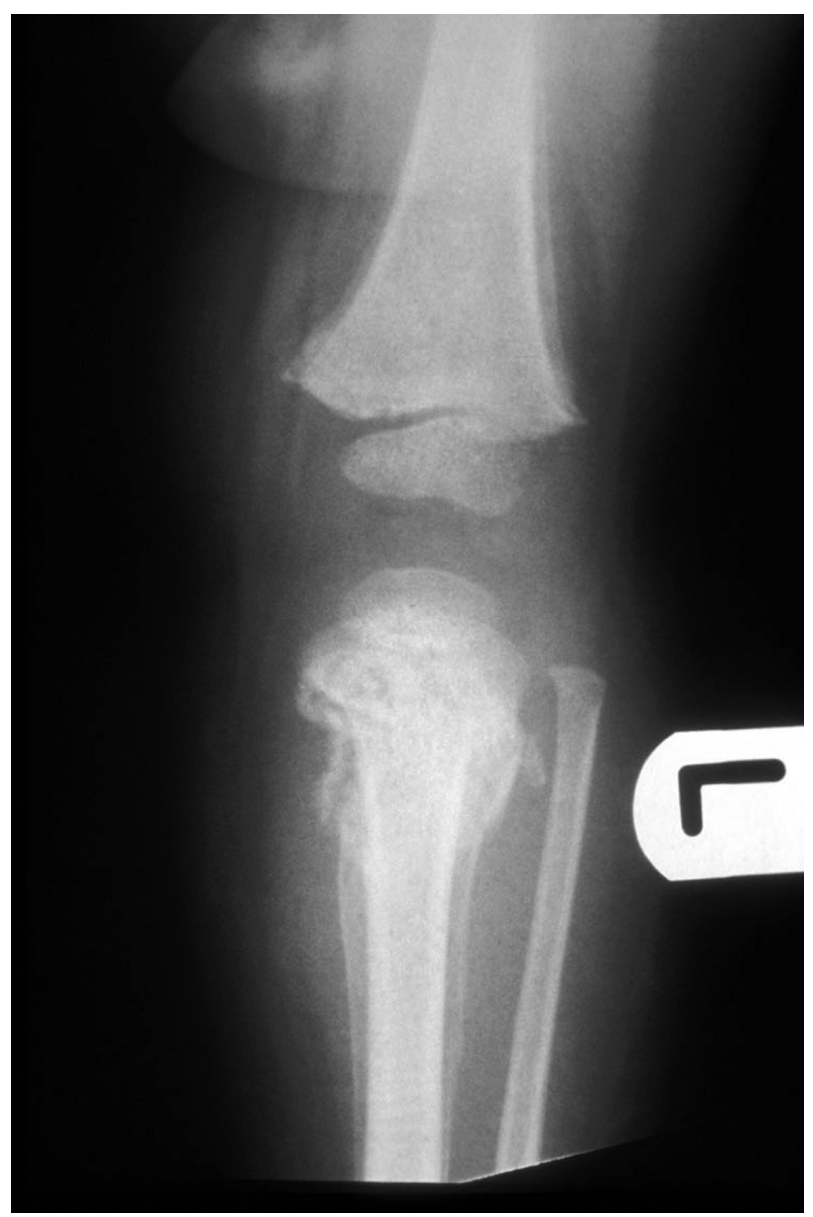

Figure I Left knee to show old fracture of the upper tibia and periosteal reactions.

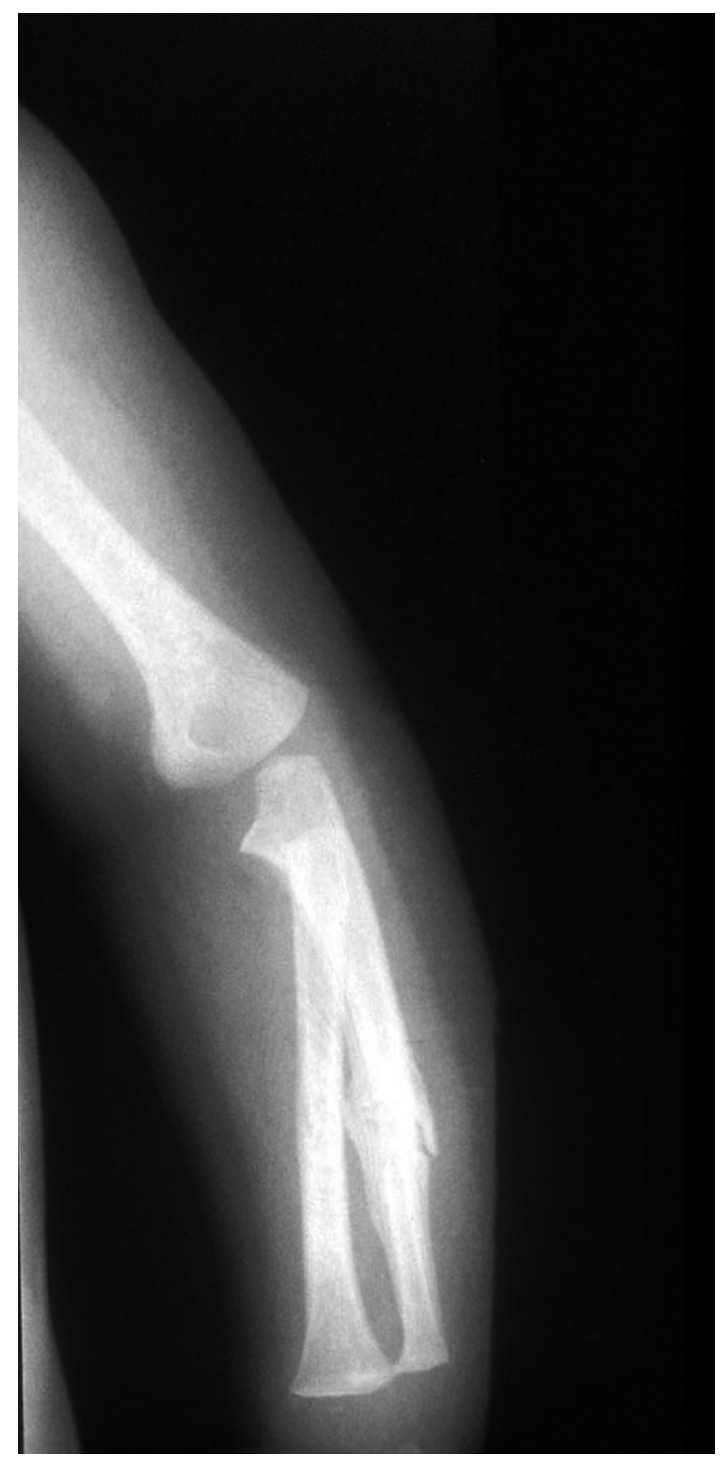

Figure $\mathbf{2}$ Left forearm to show periosteal reactions and old fracture of ulna.

carried out four days after admission. A single oral dose of $75 \mathrm{mg}$ was administered and urine collected between four and six hours later. Ascorbic acid was undetectable.

Since the fractures appeared to be of several different dates it was thought that nonaccidental injury was the most likely cause. She remained in hospital for 11 weeks under a court order. The child was returned to her mother on condition that she lived with her parents.

Her diet was described as 'probably ample in quantity but inadequate in variety'. After going home her mother was given advice on diet. The social background was unsatisfactory in that her mother was a single parent who had been living with a boyfriend who was not the child's father. However, during the long stay in hospital, there were no adverse comments on the mother or boyfriend. 
She was treated with gallows traction for the recent femur fracture for two weeks. None of the other fractures were thought to need orthopedic management. She was also given ascorbic acid. One month after admission the femur was clinically in a satisfactory position. One month later radiography showed that all the fractures were soundly united; there was no evidence of any new fractures. She was well when seen at the ages of 19 months and 24 months. No bruises were seen.

\section{Discussion}

The combination of fractures and bruising in this case was indeed suggestive of nonaccidental injury. However it seems clear that when first seen at hospital the bruising, though very large, was recent. No other superficial evidence of injury was seen and the reports that there was no bruising at the time of the earlier fractures seemed reliable. This discrepancy was suggestive of some form of brittle bone disease but there was no clinical evidence of osteogenesis imperfecta. The hematomas and the radiological evidence of subperiosteal bleeding prompted the investigation of vitamin $\mathrm{C}$ status. The results pointed to scurvy as the most likely cause of the fractures but nonaccidental injury could not be excluded.

Vitamin C deficiency is said to be common at least in adults both in the western world and in developing countries. ${ }^{18}$ It might be suggested that fractures are a rare manifestation of scurvy in the light of this single case report and only one other in the literature. ${ }^{16}$ However the rarity might simply be a reflection of the infrequency with which the diagnosis of scurvy is considered.

The investigation of vitamin $\mathrm{C}$ deficiency is unsatisfactory in that plasma ascorbic acid levels are a limited reflection of the body pool. ${ }^{19}$ While low plasma levels may reflect a low intake, low levels also occur in inflammatory episodes in which the vitamin is taken up by tissues. Leukocyte ascorbic acid assays are regarded as providing a better indicator of body stores but the assays are technically difficult and require relatively large blood samples $(2-5 \mathrm{~mL})$. The ascorbic acid saturation test is probably the most accurate index of deficiency; in one variant the patient is loaded orally with ascorbic acid over four days and, if tissue levels are normal, 60 to 80 per cent of the dose is recovered in the urine. In another form of the test, particularly valuable in children, a loading dose of $11 \mathrm{mg}$ ascorbic acid per $\mathrm{kg}$ body weight is given orally and the urinary excretion measured in the two-hour period starting four hours later when maximum excretion would be expected if the patient had adequate tissue levels. Considerable attention to detail is needed to carry out all these tests. ${ }^{19}$

Others have suggested that scurvy could be misdiagnosed as child abuse. ${ }^{20,21}$ In cases of unexplained fractures in childhood scurvy needs to be considered alongside other bone disorders. It is vital to consider the whole differential diagnosis before concluding that fractures were caused by abuse.

\section{Acknowledgments}

I am indebted to Dr Mark Fraser for his helpful discussion and encouragement to report this case. I thank Ms Kirsteen Bovill for her secretarial help.

\section{Disclosure}

No conflicts of interest were declared in relation to this paper.

\section{References}

1. Paterson CR, McAllion SJ. Classical osteogenesis imperfecta and allegations of nonaccidental injury. Clin Orthop Relat Res. 2006;452:260-264.

2. Keller KA, Barnes PD. Rickets vs abuse: a national and international epidemic. Pediatr Radiol. 2008;38:1210-1216.

3. Paterson CR. Vitamin D deficiency rickets and allegations of nonaccidental injury. Acta Paediatr. 2009;98:2008-2012.

4. Dabezies EJ, Warren PD. Fractures in very low birth weight infants with rickets. Clin Orthop Relat Res. 1997;335:233-239.

5. Paterson CR, Burns J. Copper deficiency in infancy. J Clin Biochem Nutr. 1988;4:175-190.

6. Adams PC, Strand RD, Bresnan MJ, Lucky AW. Kinky hair syndrome: serial study of radiological findings with emphasis on the similarity to the battered child syndrome. Radiology. 1974;112:401-407.

7. Bacopoulou F, Henderson L, Philip SG. Menkes' disease mimicking nonaccidental injury. Arch Dis Child. 2006;91:919.

8. Miller ME. Temporary brittle bone disease: a true entity? Semin Perinatol. 1999;23:174-182.

9. Paterson CR. Temporary brittle bone disease: fractures in medical care. Acta Paediatr. 2009;98:1935-1938.

10. Silverman FN. An unusual osseous sequel to infantile scurvy. J Bone Joint Surg Am. 1953;35:215-220.

11. Swischuk LE. Metaphyseal corner fractures in infants: a review. Emerg Radiol. 1998:103-107.

12. Eisele PH, Morgan JP, Line AS, Anderson JH. Skeletal lesions and anemia associated with ascorbic acid deficiency in juvenile rhesus macaques. Lab Anim Sci. 1992;42:245-249.

13. Tsunenari T, Fukase M, Fugita T. Bone histomorphometric analysis for the cause of osteopenia in vitamin $\mathrm{C}$-deficient rat (ODS rat). Calcif Tissue Int. 1991;48:18-27.

14. Beamer WG, Rosen CJ, Bronson RT, et al. Spontaneous fracture (sfx): A mouse genetic model of defective peripubertal bone formation. Bone. 2000;27:619-626.

15. Hasan L, Vögeli P, Neuenschwander S, et al. The L-gulono-gammalactone oxidase gene (GULO) which is a candidate for vitamin C deficiency in pigs maps to chromosome 14. Anim Genet. 1999;30:309-312.

16. Berant M, Jacobs J. A "pseudo" battered child. Clin Pediatr (Phila). 1966;5:230-237.

17. Lewis D, Carpenter C, Evans E, Thomas P. Rickets and scurvy presenting in a child as apparent non accidental injury. Internet J Orthop Surg. $2007 ; 4(2)$. 
18. Fain O. Musculoskeletal manifestations of scurvy. Joint Bone Spine. 2005; 72:124-128.

19. Gibson RS. Principles of Nutritional Assessment. 2nd ed. 2005. Oxford, UK: University Press.

20. Clemetson CAB. Child abuse or Barlow's disease. Pediatr Int. 2003;45:758.
21. Gammell C. Adoption stands despite possible miscarriage of justice, court rules. Daily Telegraph. 2009 Feb 11. Accessed Jul 282010. Available from: http://www.telegraph.co.uk/news/newstopics/ lawreports/4592069/Adoption-stands-despite-possible-miscarriageof-justice.html.

\section{Publish your work in this journal}

Orthopedic Research and Reviews is an international, peer-reviewed, open access journal focusing on the patho-physiology of the musculoskeletal system, trauma, surgery and other corrective interventions to restore mobility and function. Advances in new technologies, materials, techniques and pharmacological agents are particularly welcome. The journal welcomes

Submit your manuscript here: http://www.dovepress.com/orthopedic-research-and-reviews-journal original research, clinical studies, reviews \& evaluations, expert opinion and commentary, case reports and extended reports. The manuscript management system is completely online and includes a very quick and fair peer-review system, which is all easy to use. Visit http://www.dovepress. com/testimonials.php to read real quotes from published authors. 